\title{
Use of Silica with Immobilized 2-Nitrozo-1-Naphthol-4-Sulfonic Acid for the Sorption-Photometric Determination of Palladium
}

\author{
S. L. Didukh-Shadrina ${ }^{a, *}$, V. N. Losev ${ }^{a}$, N. V. Maznyak ${ }^{a}$, and A. K. Trofimchuk ${ }^{b}$ \\ a "Kristall" Research and Engineering Center, Siberian Federal University, Krasnoyarsk, 660041 Russia \\ ${ }^{b}$ Faculty of Chemistry, Shevchenko Kiev National University, Kiev, 01033 Ukraine \\ *e-mail:semdid@mail.ru \\ Received April 3, 2018; revised June 7, 2018; accepted February 21, 2019
}

\begin{abstract}
Silica modified with 2-nitroso-1-naphthol-4-sulfonic acid (NNS), quantitatively extracting palladium(II) from solutions in the $\mathrm{pH}$ range $1-8$, is proposed for the preconcentration and photometric determination of palladium(II) in the adsorbent phase. In the sorption of palladium(II) from solutions with $\mathrm{pH} 1-$ 3 , complex compounds of the stoichiometry Pd : NNS $=1: 2$ were formed on the adsorbent surface. They has intense lilac color and a maximum in diffuse reflectance spectrum at $550 \mathrm{~nm}$. A procedure is developed for sorption-photometric determination of palladium in the version of diffuse reflectance spectroscopy with a limit of detection $0.03 \mu \mathrm{g}$ per $0.1 \mathrm{~g}$ of the sorbent. The analytical range is $0.1-10 \mu \mathrm{g} / 0.1 \mathrm{~g}$. The procedure was tested in the determination of palladium in wastewater and water extract from the soil.
\end{abstract}

Keywords: palladium(II), nitroso-N-salt, modified silica, sorption-photometric determination

DOI: $10.1134 / \mathrm{S} 1061934819080069$

Because of its chemical and physical characteristics (catalytic effect, electric conductivity, and chemical resistance to corrosion), palladium(II) is one of the most widely used platinum-group metals in various industries: oil, dental, pharmaceutical, automotive, jewelry, etc. [1]. As a result of its active use, palladium(II) enters the environment with the industrial wastewater and exhaust gases of cars because of the deterioration of automobile catalysts. In the environment, palladium(II) interacts with organic substances, e.g., humic acids, to form stable complexes [2]. On the one hand, the degree of environmental pollution with palladium(II) is significantly lower compared to, e.g., that with $\mathrm{Cd}, \mathrm{Hg}$, $\mathrm{As}$, and $\mathrm{Pb}$. $\mathrm{On}$ the other hand, because of environmental accumulation, palladium(II) and its compounds in the future may affect human health, mammals, fish, and plant development [3], which necessitates the development of simple and highly sensitive procedures for its determination.

To determine palladium(II) in man-made and natural objects, various methods of analysis are used [4, 5], however, the complexity of the sample composition limits the sensitivity of the methods used due to matrix effects. To eliminate them and increase the sensitivity of the determination of palladium(II), its preliminary extraction [6-9] or sorption concentration [10-15] is used. The combination of sorption concentration with the subsequent spectrophotometric determination of palladium(II) directly in the phase of the sorbent is characterized by simplicity and rapidity [16]. In a number of works [17-20] for the photometric determination of palladium(II), the use of its colored complexes with nitrosonaphthols and their sulfo derivatives has been proposed. Sulfo derivatives of nitrosonaphthols are well soluble in water and make it possible to determine palladium(II) in aqueous solutions without prior extraction [18, 19].

We have proposed the use of silica with immobilized 2-nitroso-1-naphthol-4-sulfonic acid (nitroso$\mathrm{N}$-salt) for the sorption-photometric determination of palladium(II). This reagent is firmly and effectively fixed on the surface of aminated silica and is sufficiently resistant to the effects of saline media [21], which will make it possible to use it for the determination of palladium(II) in wastewater.

\section{EXPERIMENTAL}

Reagents. A solution of palladium(II) with a concentration of $1 \mathrm{~g} / \mathrm{L}$ was prepared by dissolving a weighed portion of an $\mathrm{H}_{2}\left[\mathrm{PdCl}_{4}\right]$ preparation in $1 \mathrm{M}$ $\mathrm{HCl}$. Solutions of palladium(II) with lower concentrations were prepared by diluting the stock solution with distilled water on the day of the experiment. A $5 \times$ $10^{-4} \mathrm{M}$ stock solution of 2-nitroso-1-naphthol-4-sulfonic acid sodium salt was prepared by dissolving a weighed portion of an Aldrich preparation. To create the required $\mathrm{pH}$ value, $\mathrm{HCl}$, a $\mathrm{NaOH}$ solution, and an acetate buffer solution with $\mathrm{pH} 4.0-6.5$ were used. 


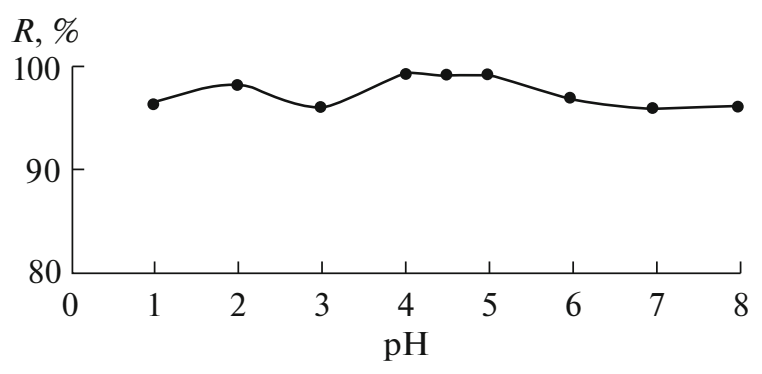

Fig. 1. $\mathrm{pH}$ dependence of the recovery of $\mathrm{Pd}(\mathrm{II})$ on $\mathrm{SiO}_{2}-$ PHMG-NNS: $m_{\text {sorb }}=0.1 \mathrm{~g}, c_{\mathrm{Pd}(\mathrm{II})}=0.5 \mu \mathrm{g} / \mathrm{mL}$, and $V_{\text {sol }}$ $=10 \mathrm{~mL}$.

Silochrome C-120 silica (fraction of $0.1-0.2 \mathrm{~mm}$, specific surface area $120 \mathrm{~m}^{2} / \mathrm{g}$, and average pore diameter $\sim 45 \mathrm{~nm}$ ) was used as the basis for the sorbent synthesis. A solution (5\%) of polyhexamethylene guanidine hydrochloride (PHMG) was prepared by dissolving a sample of the BIOPAG-D preparation (Institute of Ecological and Technological Problems, Moscow) in deionized water.

Equipment. Diffuse reflectance spectra (DRS) in the region 380-720 $\mathrm{nm}$ were recorded on a Pulsar spectrophotocolorimeter (Khimavtomatika, Russia). The diffuse reflectance spectra were presented on the coordinates: the Gurevich-Kubelka-Munk function $F(R)=(1-R)^{2} / 2 R-$ the wavelength, nm (here $R$ is the diffuse reflection coefficient). The concentration of palladium in solutions before and after sorption was determined by atomic absorption spectrometry (AAS) on an Analyst-800 spectrometer (Perkin-Elmer, USA) with a flame atomizer (acetylene-air) at a wavelength of $340.4 \mathrm{~nm}$ and a slit width of $0.2 \mathrm{~nm}$. To control the $\mathrm{pH}$ of the solutions, a SevenEasy S20 potentiometer (Mettler-Toledo, Spain) with an InLabExpertPro combined electrode was used.

Experimental procedure. The $\mathrm{SiO}_{2}-\mathrm{PHMG}-\mathrm{NNS}$ sorbent was synthesized by the sequential treatment of a silica surface with PHMG and NNS by the procedure [21]. This synthesis method gives a $\mathrm{SiO}_{2}-$ PHMG-NNS sorbent with any controlled NNS surface concentration up to a maximum of $88 \mu \mathrm{mol}$ per $1 \mathrm{~g}$ of the sorbent. In the course of synthesis, the sorbent acquired a yellow color, characteristic of the reagent.

In studying the sorption of palladium(II) in a batch mode $1 \mathrm{~mL}$ of a palladium(II) solution with a concentration of $5 \mu \mathrm{g} / \mathrm{mL}$ was injected in a $20-\mathrm{mL}$ graduated test tube with a ground glass stopper, a $\mathrm{NaOH}$ solution and/or an acetate buffer solution was added to create the required $\mathrm{pH}$ value, and distilled water was added to $10 \mathrm{~mL}$. A $0.1-\mathrm{g}$ portion of a $\mathrm{SiO}_{2}-\mathrm{PHMG}-\mathrm{NNS}$ sorbent with the surface concentration of NNS $60 \mu \mathrm{mol} / \mathrm{g}$ was added and stirred for $1-20 \mathrm{~min}$. The sorbent was separated from the solution by decantation, transferred to a fluoroplastic cell, excess water

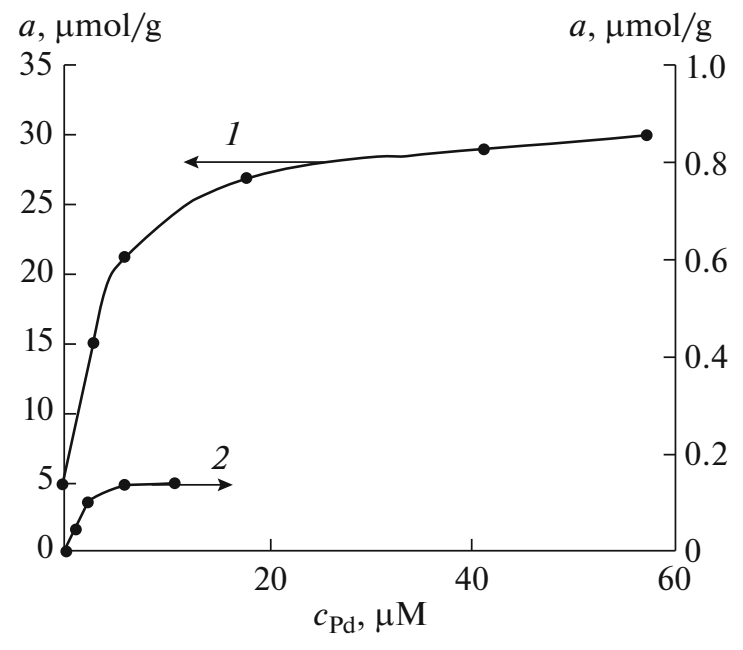

Fig. 2. Isotherms of $\mathrm{Pd}(\mathrm{II})$ sorption on (1) $\mathrm{SiO}_{2}-\mathrm{PHMG}-$ NNS and (2) $\mathrm{SiO}_{2}-\mathrm{PHMG}$ : pH 1, $c_{\mathrm{NNS}}=60 \mu \mathrm{mol} / \mathrm{g}$.

was removed with filter paper, and the diffuse reflection coefficient $(R)$ was recorded in the range 380-720 $\mathrm{nm}$. The concentration of palladium in the solution before and after sorption was determined by AAS.

\section{RESULTS AND DISCUSSION}

The recovery of palladium(II) by the $\mathrm{SiO}_{2}-$ PHMG-NNS sorbent in the $\mathrm{pH}$ range $1-8$ was $96-$ 99\% (Fig. 1). The time for the establishment of a sorption equilibrium at metal sorption on the $\mathrm{SiO}_{2}-$ PHMG-NNS sorbent at $\mathrm{pH} 1$ did not exceed $5 \mathrm{~min}$ and at $\mathrm{pH} \mathrm{5,3} \mathrm{min}$.

Palladium(II) in hydrochloric acid solutions at $\mathrm{pH} 1$ is present as negatively charged chloride and aqua chloride complexes: $\left[\mathrm{PdCl}_{4}\right]^{2-}$ and $\left[\mathrm{Pd}\left(\mathrm{H}_{2} \mathrm{O}\right) \mathrm{Cl}_{3}\right]^{-}[22]$, which can be extracted with the $\mathrm{SiO}_{2}-\mathrm{PHMG}$ sorbent by the anion-exchange mechanism. The sorption capacities of the $\mathrm{SiO}_{2}-\mathrm{PHMG}$ and $\mathrm{SiO}_{2}-\mathrm{PHMG}-\mathrm{NNS}$ sorbents for palladium(II), determined by the horizontal portions of sorption isotherms at $\mathrm{pH} 1$, were 0.14 and $30 \mu \mathrm{mol} / \mathrm{g}$, respectively (Fig. 2). The high sorption capacity of the $\mathrm{SiO}_{2}-$ PHMG-NNS sorbent for palladium(II) indicates its predominant extraction due to interactions with the NNS fixed on the silica surface. At the maximum degree of filling of the surface of the $\mathrm{SiO}_{2}-\mathrm{PHMG}$ sorbent with the reagent, there were no free amino groups of PHMG capable of interacting with palladium(II) chloride and aqua chloride complexes.

In determining the composition of the palladium(II) complex and the stability constant of the $\operatorname{Pd}(\mathrm{II})$ surface complex with the NNS, an equilibrium shift method in the version of diffuse reflectance spectroscopy was used. The concentration of palladium(II) in the solution remained constant, and the 


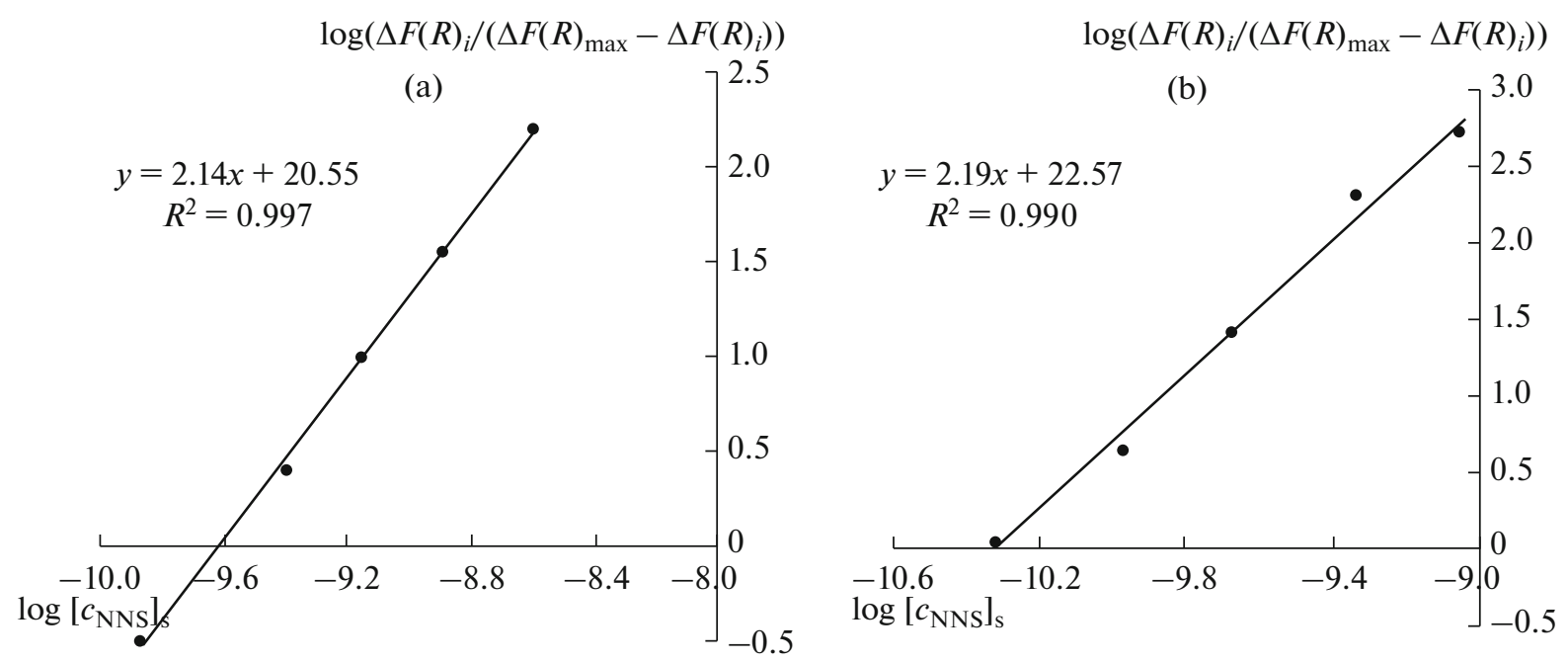

Fig. 3. Method of equilibrium shift for $\mathrm{Pd}(\mathrm{II})$ on the $\mathrm{SiO}_{2}-\mathrm{PHMG}-\mathrm{NNS}$ surface: $\mathrm{pH}$ (a) 1 , (b) $5 ; m_{\mathrm{sorb}}=0.1 \mathrm{~g} ; c_{\mathrm{Pd}(\mathrm{II})}=$ $0.2 \mu \mathrm{g} / \mathrm{mL}$; and $V_{\text {sol }}=10 \mathrm{~mL}$.

surface concentration of the reagent, NNS, was varied. The Pd (II) : NNS ratio and the logarithm of the stability constant $(\log \beta)$ were determined from the graph of the dependence $\log \left(\Delta F(R)_{i} /\left(\Delta F(R)_{\max }-\right.\right.$ $\left.\left.\Delta F(R)_{i}\right)\right)-\log [\mathrm{NNS}]_{\mathrm{S}}\left(\right.$ Fig. 3), where $\Delta F(R)_{\max }$ is the difference between the $F(R)$ functions of the maximum value and of the blank experiment, $\Delta F(R)_{i}$ is the difference between the values of $F(R)$ of the $i$-th and blank experiments, and [NNS $]_{\mathrm{s}}$ is the equilibrium surface concentration of the reagent. Based on the equation $\log \left(\Delta F(R)_{i} /\left(\Delta F(R)_{\max }-\Delta F(R)_{i}\right)\right)=\log \beta m / V+$ $\log [\mathrm{NNS}]_{\mathrm{s}}$, the value $\log \beta m / V$ is numerically equal to the intercept on the $y$-axis. As the $m / V$ ratio is $10^{-2}$, the stability constant of the palladium(II) surface complex with NNS is $\log \beta=22.55$ at $\mathrm{pH} 1$ and $\log \beta=24.57$ at $\mathrm{pH}$ 5. The stoichiometry of the surface complex is $\operatorname{Pd}(\mathrm{II}): \mathrm{NNS}=1: 2$ and does not depend on the $\mathrm{pH}$ of the solution.

The spectroscopic characteristics of palladium(II) complexes formed on the surface of the $\mathrm{SiO}_{2}-$ PHMG-NNS sorbent were studied at the surface NNS concentration $2 \mu \mathrm{mol} / \mathrm{g}$ of sorbent, because at a higher surface concentration of the reagent, the sorbents have intense yellow color.

In the sorption of palladium(II) at $\mathrm{pH} 1$, the surface of the $\mathrm{SiO}_{2}-\mathrm{PHMG}-\mathrm{NNS}$ sorbent, initially colored in yellow, becomes colorless, and then is gradually colored in violet. This effect is due to the desorption of NNS from the sorbent surface, the formation of the $\left[\mathrm{Pd}(\mathrm{NNS})_{2}\right]^{2-}$ complex in solution, which is sorbed on the positively charged $\mathrm{SiO}_{2}-$ PHMG surface. With an increase in the $\mathrm{pH}$ of palladium(II) solutions to $\mathrm{pH} 2-3$, a decrease in the intensity of violet color is observed. At $\mathrm{pH} \geq 4$, the sorbent turns brown in the process of sorption. The maximum intensity of the brown color is preserved in the $\mathrm{pH}$ range of 4-7, which coincides with the region of quantitative recovery of NNS by the $\mathrm{SiO}_{2}-\mathrm{PHMG}$ sorbent [21]. The diffuse reflectance spectra of surface complexes of palladium(II) with NNS at different $\mathrm{pH}$ values are shown in Fig. 4. During the extraction of palladium(II) complex with 2-nitroso-1-naphtol in toluene, similar colors of the extracts from violet to redbrown were observed at various $\mathrm{pH}$ values of the solutions [20].

The diffuse reflectance spectra of palladium(II) surface complexes obtained at $\mathrm{pH} 1$ represent a broad band with a maximum at $550 \mathrm{~nm}$ (Fig. 4). With an increase in the palladium(II) concentration at $\mathrm{pH} 1$ on the $\mathrm{SiO}_{2}-\mathrm{PHMG}-\mathrm{NNS}$ surface, the color intensity of the sorbent increases proportionally without a change in the position of the maximum of the DRS (Fig. 5).

At $\mathrm{pH}$ values $\geq 4$, a broad band with an intense maximum at $440 \mathrm{~nm}$, corresponding to the adsorbed NNS, and a low-intensity band with a maximum at $540 \mathrm{~nm}$, corresponding to the absorption of the surface complex of palladium(II) with NNS, were observed in the DRS of the sorbents. With an increase in palladium concentration on the sorbent surface in the DRS, the intensity of the maximum at $440 \mathrm{~nm}$ decreased, which was due to the coordination of the NNS in the complex with palladium, and the intensity of the band with a maximum at $540 \mathrm{~nm}$ increased (Fig. 6). When the palladium(II) concentration was $10 \mu \mathrm{g}$ per $0.1 \mathrm{~g}$ of sorbent, the maximum corresponding to free NNS disappeared, which was due to its full coordination with palladium and the formation of the surface complex $\left[\mathrm{Pd}(\mathrm{NNS})_{2}\right]^{2-}$.

The time of color development of palladium surface complexes corresponds to the time for the estab- 


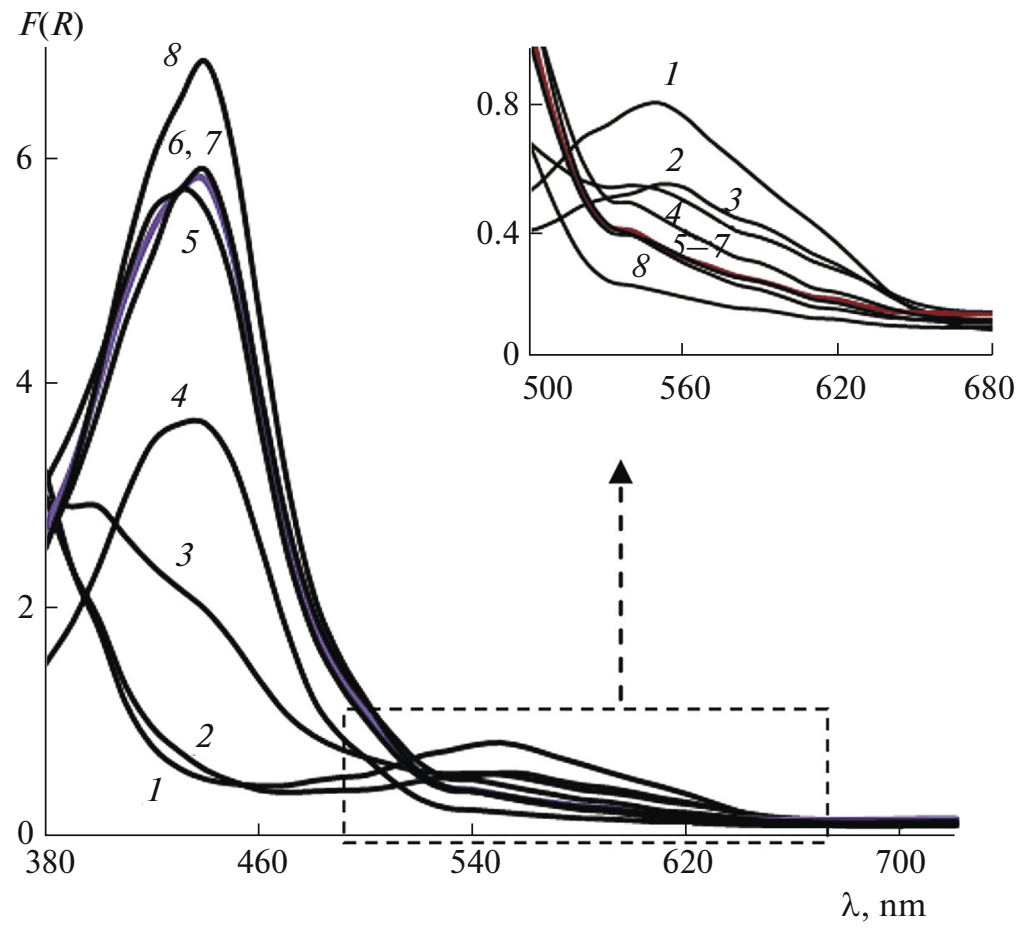

Fig. 4. Diffuse reflectance spectra of a $\mathrm{Pd}(\mathrm{II})$ surface complex on $\mathrm{SiO}_{2}-\mathrm{PHMG}-\mathrm{NNS}: m_{\mathrm{sorb}}=0.1 \mathrm{~g} ; c_{\mathrm{Pd}(\mathrm{II})}=0.2 \mu \mathrm{g} / \mathrm{mL} ; V_{\text {sol }}=$ $10 \mathrm{~mL} ; \mathrm{pH}(1) 1,(2) 2$, (3) 3, (4) 4, (5) 5, (6) 6, (7) 7, and (8) 8.

lishment of a sorption equilibrium and is 3 min at pH 5 and $5 \mathrm{~min}$ at $\mathrm{pH} 1$.

Sorption-photometric determination of palladium. As NNS at $\mathrm{pH}>4$ forms colored complexes with a number of nonferrous and heavy metals [21, 23-25], for the development of a sorption-photometric pro-

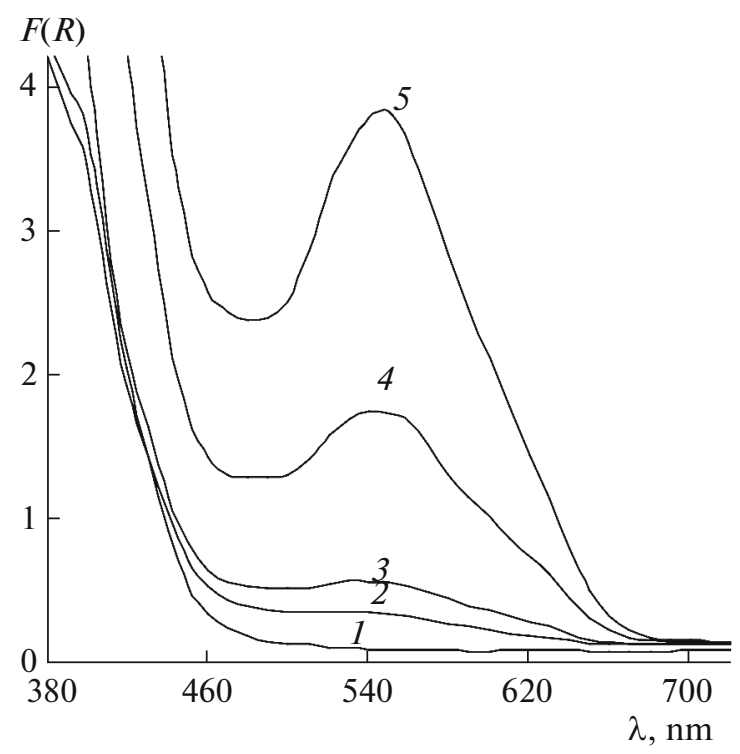

Fig. 5. Diffuse reflectance spectra of a Pd(II) surface complex on $\mathrm{SiO}_{2}-\mathrm{PHMG}-\mathrm{NNS}$ at $\mathrm{pH} 1: m_{\mathrm{sorb}}=0.1 \mathrm{~g} ; c_{\mathrm{Pd}(\mathrm{II})}$, $\mu \mathrm{g} / 0.1 \mathrm{~g}$ of sorbent: (1) 0, (2) 1 , (3) 2 , (4) 5 , and (5) 10 . cedure for determining palladium, we studied the formation of intensely colored surface complexes at $\mathrm{pH} 1$, at which free NNS is absent from the surface of the sorbent and the contrast of the complexation reaction of palladium was higher than that at $\mathrm{pH} 5$.

Construction of calibration dependence. From 0.1 to $15 \mu \mathrm{g}$ of palladium(II) as a solution in $1 \mathrm{M} \mathrm{HCl}$ is

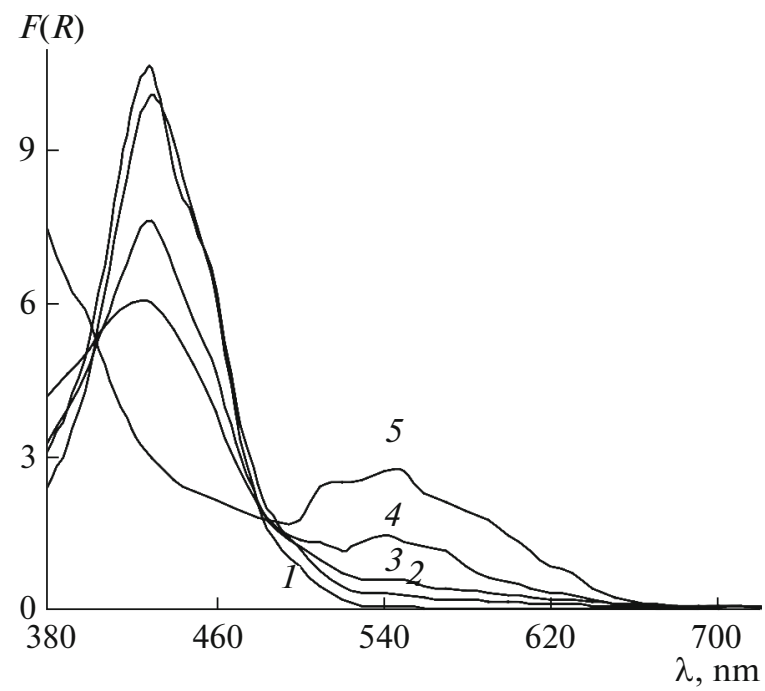

Fig. 6. Diffuse reflectance spectra of a $\mathrm{Pd}(\mathrm{II})$ surface complex on $\mathrm{SiO}_{2}-\mathrm{PHMG}-\mathrm{NNS}$ at $\mathrm{pH} 5: m_{\mathrm{sorb}}=0.1 \mathrm{~g} ; c_{\mathrm{Pd}(\mathrm{II})}$, $\mu \mathrm{g} / 0.1 \mathrm{~g}$ of sorbent: (1) 0, (2) 1, (3) 2 , (4) 5 , and (5) 10 . 
Table 1. Results of sorption-photometric determination of palladium(II) in the wastewater of the palladating of printed circuit boards and in a aqueous soil extract using a $\mathrm{SiO}_{2}-$ PHMG-NNS sorbent $\left(m_{\text {sorb }}=0.1 \mathrm{~g}, V_{\text {sample }}=5 \mathrm{~mL}, n=5\right.$, and $P=0.95$ )

\begin{tabular}{|c|c|c|}
\hline Added, $\mu \mathrm{g}$ & Found, $\mu \mathrm{g}$ & $\mathrm{RSD}, \%$ \\
\hline \multicolumn{3}{|c|}{ Wastewater } \\
\hline 0 & $0.62 \pm 0.05$ & 7 \\
\hline 1 & $1.5 \pm 0.1$ & 6 \\
\hline 2 & $2.6 \pm 0.2$ & 6 \\
\hline \multicolumn{3}{|c|}{ Aqueous soil extract } \\
\hline 0 & - & \\
\hline 0.5 & $0.51 \pm 0.04$ & 7 \\
\hline 1.0 & $1.02 \pm 0.08$ & 7 \\
\hline
\end{tabular}

placed in a number of $20-\mathrm{mL}$ graduated test tubes with ground glass stoppers, and distilled water is added to a total volume of $10 \mathrm{~mL}$. A 0.1 -g portion of a $\mathrm{SiO}_{2}-$ PHMG-NNS sorbent with a reagent concentration of $2 \mu \mathrm{mol}$ per $1 \mathrm{~g}$ of the sorbent is introduced; the test tubes are closed with stoppers and their contents are stirred for $5 \mathrm{~min}$. The sorbents are separated from the solution by decantation, transferred to a fluoroplastic cell, excess water is removed by filter paper, and the diffuse reflection coefficient is measured at $550 \mathrm{~nm}$. The detection limit for palladium, calculated by the $3 \mathrm{~s}$ test, is $0.03 \mu \mathrm{g}$ per $0.1 \mathrm{~g}$ of the sorbent. The linearity of the calibration dependence is maintained in the concentration range $0.1-10 \mu \mathrm{g}$ of palladium(II) per $0.1 \mathrm{~g}$ of the sorbent and is described by the equation $\Delta F(R)=(0.39 \pm 0.02) c$, where $c$ is the concentration of palladium on the sorbent surface.

The selectivity of the sorption-photometric determination of palladium was studied in binary systems containing $0.05 \mu \mathrm{g} / \mathrm{mL}$ of palladium(II) and from 0.05 to $50 \mu \mathrm{g} / \mathrm{mL}$ of other metal ions. The determination of $0.5 \mu \mathrm{g}$ of palladium(II) per $0.1 \mathrm{~g}$ of the sorbent at $\mathrm{pH} 1$ does not interfere (in multiples) with $\mathrm{Na}(\mathrm{I})$, $\mathrm{K}(\mathrm{I}), \mathrm{Ca}(\mathrm{II}), \mathrm{Mg}(\mathrm{II}), \mathrm{Sr}(\mathrm{II}), \mathrm{Al}(\mathrm{III})\left(10^{3}\right), \mathrm{Pb}(\mathrm{II})$, $\mathrm{Cd}(\mathrm{II}), \mathrm{Mn}(\mathrm{II}), \mathrm{Zn}(\mathrm{II}), \mathrm{Cr}(\mathrm{III})\left(10^{2}\right), \mathrm{Ni}(\mathrm{II}), \mathrm{Fe}(\mathrm{III})$ (50), $\mathrm{Fe}(\mathrm{II}), \mathrm{Cu}(\mathrm{II})$ (25), Co(II) (10).

The developed procedure was used to determine palladium in wastewater of the palladating of printed circuit boards and a water extract from soil.

The procedure for determination of palladium in wastewater of the palladating of printed circuit boards and in a water extract from soil. A water extract from soil was obtained according to the procedure [26]. Five milliliters of wastewater or a water extract from soil were injected into a graduated test tube with a ground glass stopper, $1 \mathrm{~mL}$ of $1 \mathrm{M} \mathrm{HCl}$, and water to a total volume of $10 \mathrm{~mL}$ were added. The $0.1 \mathrm{~g}$ of the sorbent was brought and the mixture was stirred for $5 \mathrm{~min}$. The sorbent was separated from the solution by decantation, transferred to a fluoroplastic cell, the excess water is removed with filter paper, and the diffuse reflection coefficient was measured at $550 \mathrm{~nm}$. The concentration of palladium was found by a calibration curve.

The results of the determination of palladium(II) are summarized in Table 1. The accuracy of the results obtained was confirmed by the spike-recovery test.

\section{FUNDING}

The work supported by the Ministry of Science and Higher Education of the Russian Federation, grant no. 4.6343.2017 for the Siberian Federal University.

\section{REFERENCES}

1. Nordberg, G.F., Flower, B., Nordberg, M., and Friberg, L., Handbook on the Toxicology of Metals, New York: Academic, 2007, 3rd ed.

2. Moldovan, M., Anal. Bioanal. Chem., 2007, vol. 388, p. 537.

3. Gagnon, Z., Newkirk, C., and Hicks, S., J. Environ. Sci. Health, 2006, vol. 41, no. 3, p. 397.

4. Rao, C. and Reddi, G., TrAC, Trends. Anal. Chem., 2000, vol. 19, no. 9, p. 565.

5. Machado, R.C., Amaral, C., Schiavo, D., Nóbrega, J.A., and Nogueira, A.R., Microchem. J., 2017, vol. 130, p. 271.

6. Mohammadi, S.Z., Afzali, D., Taher, M.A., and Baghelani, Y., Microchim. Acta, 2010, vol. 168, no. 1, p. 123.

7. Ruhela, R., Sharma, J.N., Tomar, B.S., Hubli, R.C., and Suri, A.K., Talanta, 2011, vol. 85, p. 1217.

8. Amin, A.S., Arabian J. Chem., 2016, vol. 9, p. 326.

9. Mohammadi, S., Afzali, D., and Pourtalebi, D., J. Anal. Chem., 2011, vol. 66, no. 7, p. 620.

10. Shuo Lin, Wei Wei, Xiaohui Wu, Tao Zhou, Juan Mao, and Yeoung-Sang Yun, J. Hazard. Mater., 2015, vol. 299, p. 10.

11. Awual, Md.R., Khaleque, Md.A., Ratna, Y., and Znad, H., J. Ind. Eng. Chem., 2015, vol. 21, p. 405.

12. Shaheen, H.A., Marwani, H.M., and Soliman, E.M., J. Mol. Liq., 2017, vol. 232, p. 139.

13. Mladenova, E., Dakova, I., Karadjova, I., and Karadjov, M., Microchem. J., 2012, vol. 101, p. 59.

14. Woińska, S. and Godlewska-Żyłkiewicz, B., Spectrochim. Acta, Part B, 2011, vol. 66, p. 522.

15. Bilba, D., Paduraru, C., and Tofan, L., Microchim. Acta, 2004, vol. 144, no. 1, p. 97.

16. Zolotov, Yu.A., Tsyzin, G.I., Dmitrienko, S.G., and Morosanova, E.I., Sorbtsionnoe kontsentrirovanie mikrokomponentov iz rastvorov (Adsorption Preconcentration of Trace Components from Solutions), Moscow: Nauka, 2007.

17. Marczenko, Z. and Balcerzak, M., Spektrofotometryczne metody $w$ analizie nieorganicznej (Spectrophotometric Method in Inorganic Analysis), Warsaw: Wydawnictwo Naukowe PWN, 1998.

18. Sirén, H. and Riekkola, M.-L., Microchim. Acta, 1986, vol. 90 , nos. $3-4$, p. 159. 
19. Ivanov, V.M., Samarina, T.O., and Figurovskaya, V.N., Moscow Univ. Chem. Bull. (Engl. Transl.), 2010, vol. 65, no. 4, p. 249.

20. Cheng, K.L., Anal. Chem., 1954, vol. 26, p. 1894.

21. Didukh, S.L., Losev, V.N., Mukhina, A.N., Maksimov, N.G., and Trofimchuk, A.K., J. Anal. Chem., 2017, vol. 72, no. 1, p. 49.

22. Buslaeva, T.M. and Simanova, S.A., Russ. J. Coord. Chem., 1999, vol. 25, no. 3, p. 151.

23. Taher, M.A. and Puri, B.K., Analyst, 1995, vol. 120, no. 5 , p. 95 .
24. Taher, M.A., Dehzoei, A.M., Puri, B.K., and Puri, S., Anal. Chim. Acta, 1998, vol. 367, nos. 1-3, p. 55.

25. Motomizu, Sh., Kuwabara, M., and Oshima, M., Bunseki Kagaku, 1994, vol. 43, no. 8, p. 621.

26. $R D$ (Engineering Documentation) 52.18.286-91: Methods for Measuring the Mass Fraction of Water-Soluble Forms of Metals (Copper, Lead, Zinc, Nickel, Cadmium, Cobalt, Chromium, Manganese) in Soil Samples by Atomic Absorption, Moscow, 1991.

Translated by $V$. Kudrinskaya 